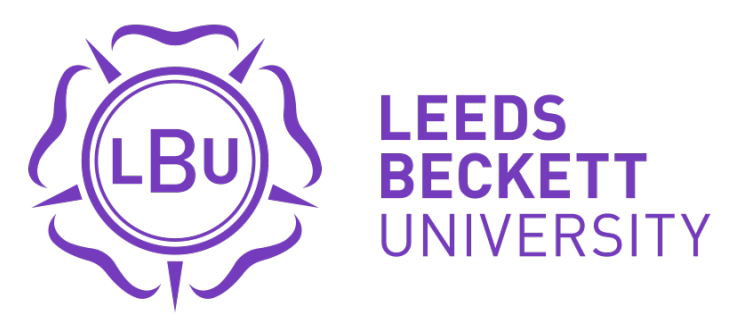

Citation:

De Angelis, M (2019) Female Asylum Seekers: A Critical Attitude on UK Immigration Removal Centres. Social Policy and Society. ISSN 1474-7464 DOI: https://doi.org/10.1017/S1474746419000216

Link to Leeds Beckett Repository record:

https://eprints.leedsbeckett.ac.uk/id/eprint/5733/

Document Version:

Article (Accepted Version)

(C) Cambridge University Press 2019

The aim of the Leeds Beckett Repository is to provide open access to our research, as required by funder policies and permitted by publishers and copyright law.

The Leeds Beckett repository holds a wide range of publications, each of which has been checked for copyright and the relevant embargo period has been applied by the Research Services team.

We operate on a standard take-down policy. If you are the author or publisher of an output and you would like it removed from the repository, please contact us and we will investigate on a case-by-case basis.

Each thesis in the repository has been cleared where necessary by the author for third party copyright. If you would like a thesis to be removed from the repository or believe there is an issue with copyright, please contact us on openaccess@leedsbeckett.ac.uk and we will investigate on a case-by-case basis. 


\title{
Female Asylum Seekers: A Critical Attitude on UK Immigration Removal Centres
}

\author{
Maria De Angelis \\ Leeds School of Social Sciences, Leeds Beckett University \\ E-Mail: M.De-Angelis@leedsbeckett.ac.uk
}

The context to this article is sovereign biopower as experienced by female asylum seekers in the confined spaces of UK Immigration Removal Centres (IRCs). With approximately 27,000 migrants entering immigration detention in 2017, the UK's immigration detention estate is one of the largest in Western Europe. Through an empirical study with former detainees, this article outlines how women experience Agamben's politically bare life through IRC practices which confine, dehumanise, and compound their asylum vulnerabilities. It also explains how micro transgressions around detention food, social relations, and faith practices reflect a Foucauldian critical attitude and restore a degree of political agency to asylum applicants. Centrally this article argues that everyday acts of resistance - confirming their identities as human / gendered / cultural beings with social belonging - can be read as political agency in women's questioning of their asylum administration. As such, this article offers a rare insight on biopower and political agency as lived and performed by women inside the in/exclusive spaces of the IRC.

Key words: Asylum seeker, detention, immigration removal centres (IRCs), in/exclusion, political agency 


\section{Introduction}

This article provides an insight on political agency as performed by female asylum seekers inside UK immigration removal centres (IRCs) ${ }^{1}$. Accessing former detainees living in a Yorkshire city during 2016, participants were asked about their experiences of life inside immigration detention. The research aim was to explore how women's micro acts of resistance build understanding of political agency in complex and volatile sites of enclosure and removal. Since the doors of the IRC remain typically shut to researchers, this article adds a perspective from lived experience to the call for greater 'empirically informed' scrutiny of life inside the IRC (Bosworth and Kellezi, 2016:12).

Critical inquiry into immigration detention traces political agency along sovereign-drawn lines of in/exclusion from full political life (Agamben, 1998, 2005; Hall, 2010). Accordingly for some researchers, resistance is actualised by embracing the violence inscribed by the state on the bodies of non-citizens. In this standpoint, agency is politically enacted through violent bodily selfactions of lip sewing, eye socket binding, and suicide (Edkins and Pin-Fat, 2004; 2005; Puggioni, 2014). For others, political resistance to sovereign power is framed in refusal / rejection of an abject or insignificant life imposed on nonnationals. In this framing, agency is displayed in purposeful acts of criminal damage, document burning, building occupation, legal complaint, and hunger strikes (Ziarek, 2008; Ellermann, 2010; McGregor, 2011; McNevin, 2011; Bosworth, 2012; Conlon, 2016). For ethnographic researchers, the possibility of political agency (albeit heavily constrained) exists in the liminal conditions and practices of waiting, uncertainty (Turnbull, 2015), and emotionality within the IRC (Hall, 2010; 2012). Irrespective of their different positions on resistance, such standpoints stoke critical conversations of what is political inside detention and, crucially, how political agency is performed by actors without rights of citizenship or belonging. 
Focussing on ex-detainees' accounts of everyday treatment and activity inside the IRC, the article utilises Agamben's work on bare life (physical existence) inside the camp to comprehend political insignificance (1998; 2005), and Foucault's critical attitude on governance to theorize political agency (1997). In neither accepting conditions of bare life nor refusing to be managed, this article argues that women's micro acts of transgression follow a Foucauldian critical attitude or questioning of governance like that, by these people, at this price' (ibid: 75 ), which can be read as political agency because they disrupt orderly migration administration. Political agency is thus legible in micro-transgressions which re-situate detainees back in administrative sight, as asylum applicants with human / gendered / cultural subjectivities and social belonging. Juxtaposing these two perspectives provides a way of capturing both narratives - political dispossession and political presence - since under Agambenian analysis $(1998 ; 2000)$ resistance demands a new form of politics one without sovereignty and its arsenal of powers to verify, surveil, and exclude individuals ${ }^{2}$. Within this article, abjectifying sovereign acts are explored through routine institutional practices of transportation, night-time deportations, and prison-like confinement which dehumanise, degrade, and compound existing asylum fears and vulnerabilities. Acting politically is explored through micro transgressions surrounding detention food, free-association and faith practices, for their challenge to women's administrative reification as deportable bodies.

\section{Biopower, Borders and Camps}

Globally and locally, the camp is intrinsically bound to the sovereign management of migrant bodies (Bloch and Schuster, 2005). Widely used in the post-World War II administration of political refugees (Malkki, 1995), the camp is now embedded in modern-day regulation of migratory flows and racialised bodies. For an example of reception-transit camps - see Lampedusa, Italy; planned-managed camps - see Roszke, Hungary; 'special' penal camps - see 
Saualm Alp, Austria; and unofficial migrant camps -see the Calais Jungle, France (Fekete, 2008; McHugh, 2015; UNHCR, 2016). As witnessed in Australia's 'protection assessments at sea' and consequential enclosure and expulsion of foreigners from Manus Island, biopower - power over life within these sites - is globally visible in sovereign practices of detention and deportation (Doherty and Davidson, 2017). As Bauman (2004:56) observes, so powerful is the sovereign pronouncement on in/exclusion that 'were there no immigrants knocking at the doors, they would have to be invented'.

Echoing this global sovereign approach to managing mobility, the UK's immigration estate houses eight Immigration Removal Centres (IRCs) ${ }^{3}$, three residential short-term holding facilities (STHF), one pre-departure accommodation for families (PDA) ${ }^{4}$, and an estimated 400 additional beds in the prison estate. According to the Global Detention Project, this amounts to a dozen facilities fitting classification as immigration detention sites (GDP, 2016: 24 ), with space to hold between 2,500 and 3,500 people on any given day (Silverman and Griffiths, 2018). Included in this figure are persons labelled illegal or irregular - amongst them those arriving without documents, refused asylum seekers, visa over-stayers ${ }^{5}$, and those deemed deviant and dangerous foreign national offenders (FNOs) - although prisoners serving 12 months or more typically remain in prison pending an automatic deportation (UK Borders Act, 2007; Aliverti, 2016).

During the year of the study - 2016 - Home Office (2017a) statistics recorded approximately 29,000 individuals as detained in IRCs, short-term holding facilities and pre-departure accommodation, with approximately 11,000 as enforced removals (enforced removal statistics combine those expelled from inside one of these centres and post-detainees in the process of being deported within this head count). Although detainees are overwhelmingly younger males, women made up one-sixth of the numbers in 2016 (Home Office, 2017b) with 
the female to male ratio averaging one female per nine male detainees over the last five years (McGuiness and Gower, 2017). Irrespective of gender, ethnicity, or facility, almost all had claimed asylum at some point during immigration proceedings (Silverman, 2017).

\section{IRCs as sites of biopower}

For Agamben (1997: 95), the camp - in the archetypal concentration camps of World War II, and their modern equivalents in terrorist detention centres, military prisons, refugee compounds, and quasi-carceral immigration removal centres signifies the political space of modernity, where the distinction between being human in a bodily organism way, and being human as in ethically and politically relevant, is drawn along in/exclusive lines decided by the state. As Hall (2010: 883) observes, 'the camp is the concretisation of the exception where rule and exception...merge'. From this standpoint, a 'state of encampment' can materialise wherever this 'paradoxical positioning' (Darling, 2009: 651), as outside juridical protection but not outside its application, exists. Although disagreements surround the IRC as a modern reproduction of the camp, (see Levy, 2010, for a critique of refugee sites under this umbrella term), many see utility in the logic and language of camps for the plight of asylum seekers (see Puggioni, 2006; Darling, 2009). Others recognise within these modern reproductions an ethos of biopower redolent of the marginalisation and violence marking traditional camp space (see De Genova, 2010; Fassin, 2011; Canning, 2014). As evidenced in the Panorama (2017) undercover report on brutality in an all-male facility 'Brook House': 'We don't cringe at breaking bones. If I killed a man, I wouldn't be bothered. I'd carry on'6. As O' Donoghue (2015) reflects, it is not the atrocities that take place there which define the camp, but the potential that atrocities may take place there which does. Just two years after Chanel 4's (2015) exposé of Yarl's Wood', an all-female facility in which black, minority, ethnic women alleged racial and sexual abuses, the liminal figure of 
homo sacer - the social outcast of Roman history, denied citizen rights and reduced to bare [politically insignificant] life (Agamben, 1998:12) - reappears in today's asylum seeker (Ellermann, 2010). With G4S still in charge of Brook House and Serco still running Yarl's Wood, private custodial firms now manage all IRCs except Morton Hall run by Her Majesty's Prison Service (Silverman and Griffiths, 2018). Although prison-run centres are arguably no more sustainable nor more creative than their private sector counterparts, their edge lies in greater public accountability for individual or institutional harms on those in their care and custody ${ }^{8}$. Additionally, as Canning (2017) notes, outsourcing encourages an expansion of the detention estate for private sector gain.

As clearly exampled in immigration detention without criminal charge, people seeking asylum are under the authority of (included within) state law and simultaneously denied (excluded from) the legal rights and protections afforded to citizens and national prisoners. Against this abjectifying political order, the IRC itself becomes an ambiguous political space, in which detainees hold the potential to disrupt ordered migration governance (Nyers, 2004; Ellermann, 2010; Rygiel, 2011; Amoore and Hall, 2013). Viewed under the Foucauldian lens of a critical attitude, resistance to authority within the IRC is not to be confused with an outright opposal of governance - 'something that would be a fundamental anarchism, that would be like an originary freedom, absolutely and wholeheartedly resistant to any governmentalization' (Foucault, 1997: 75). Rather, in the personal accounts that follow, women's questioning of IRC practices, as performed in everyday activities and micro transgressions inside detention, is shown to interfere with their political ordering as bare lives without political presence - the litmus test of a critical attitude in this study.

\section{The Study}

Given that former detainees are a hard to access group, the research call was advertised through posters, email correspondence, and personal contact with 
local organisations during the first six months of 2016. Whilst formal introductions from project leaders within the non-governmental sector established independence from ongoing UK Border Agency (UKBA) inquiries, its success is down to participants who snowballed the call amongst their networks of post-detainee friends, resulting in fifteen respondents. In response to concerns over information falling into the wrong hands, women's right to withdraw research consent was stressed, alongside a guarantee of anonymity covering all names and institutions - hence reference to the IRC - since naming specific IRCs increased fears of identification and reprisal. Women's control over sensitive disclosure was also emphasised. In line with refugee agency guidelines on sanctuary (Barnett and Bhogal, 2009), respondents were offered hospitality ${ }^{9}$ and compensated $£ 20.00$ on arrival, irrespective of whether or not they stayed for a (semi-structured) interview (see Critchley, 2000, for ethical discussion of unconditional hospitality). Apart from one cash-refuser (who viewed the sum as 'just too little') ${ }^{10}$, there was genuine delight over cash payment given the dehumanising use of vouchers and cards in asylum governance (Carnet et al, 2014). This 'social relation' dynamic produced from combining hospitality and reciprocity softened the positional gap between researcher and researchee, allowing greater space for narrative-led accounts to be told ${ }^{11}$. In looking to facilitate dialogue on a difficult story, Socratic or openstyle questioning (Hollway and Jefferson, 2000) was used to unpack and explore issues of power, control, pain, autonomy and agency. Examples of these include: Can you tell me where you were detained and why? Can you describe what your living conditions inside the IRC were like? Can you describe a good / bad day and why it was good /bad? Can you tell me what I should have asked you? The latitude in this line of questioning allows women to ascribe their own meanings to experiences and stay in control of their personal stories, whilst allowing the interviewer to search for dynamics beyond the commonplace. 


\section{Participants and patterns}

All fifteen former detainees were living in the same Yorkshire city when interviewed. Although the youngest interviewee was twenty-two and the eldest sixty-three, women were mostly aged between twenty and forty-five when detained reflecting a relatively youthful trend within the detainee population (Bosworth, 2012). The women hailed from nine different countries and, again, support findings of asylum seekers arriving from former British colonies and war-torn countries (Bosworth, 2017) - the exception being a student from Bolivia. Most had dependants either living with them in the UK or with family members back home and, at the time of interview, the majority of these children were under the age of ten. Women's mode of arrest varied: three women were detained on arrival at a UK airport; four whilst reporting at the local UKBA reporting centre; four as part of a home dawn raid; two from their place of work; one was detained after a concerned member of the public saw her collapsed on the street and phoned for an ambulance - triggering Police and Border Control alerts; and one was detained boarding the ferry for Ireland. Most were detained more than once, some only in the IRC and others also in short-term holding facilities and pre-departure accommodation whilst toing and froing between IRC and airport. The shortest singleton stay was six days in a pre-departure facility for single parents and the longest singleton stay was twelve months in the IRC. Generally, participants reproduce official trends for relatively short singleton stays in detention. In this study, eight women were held for less than two months; four between two and four months; and three between six and twelve months - though the middle band expands significantly when an individual's trajectory is totalled. As Silverman (2017) notes, trajectories of multiple detention are likely to stay hidden as long as entry, exit, and re-admittance are statistically counted as separate incidents. Aside from one long term British resident who attained citizenship post IRC release, the majority of participants 
had an inconclusive immigration status - reflecting the precarity of immigration decision making.

Analysis and limitations

Researching any closed experience carries bias, not least to the integrity of representations. Accuracy may be the goal of transcription, but when the field is immigration detention, understanding the imperative for asylum is contingent on the researcher's knowledge of global politics and diverse cultures. Participants, too, may self-censor what information is shared in interview particularly if their asylum cases are ongoing (Bosworth and Kellezi, 2016). Against such formidable constraints, researching experience always brings supplementary knowledge of people, countries, and processes we wish to understand (Bosworth et al, 2011). Braun and Clarke's (2006) thematic analysis was chosen for its ability to recognise patterns, similarities and differences within this qualitative data. An in-depth reading of transcripts generated initial codes. Codes were matched with textual dialogue and then painstakingly refined to identify central themes. Central themes were regrouped into two categories reflective of the study's rationale: bare life (for example, dehumanisation, vulnerability, confinement) and transgressive actions/reactions (for example, identity, belonging and ethical care). Placing women's voices centre-stage, the quotes below reflect findings across the two categories.

\section{Findings}

Bare life (dehumanisation, vulnerability, confinement)

Although the research was primarily interested in resistance, women routinely talked about their dehumanisation before sharing their creativity within the spaces and processes of the IRC. Bare life is rooted in sovereign distinctions between citizen and other and imposed through routine institutional practices which diminish non-citizens as people. For some, this dehumanisation is 
animalistic in nature and intent, and designed to strip them of human status and rights. This is Kia's description of her transportation to the IRC:

They went to put me in the van, a van full of pooh and vomit. It was like looking into a toilet. I didn't want to go in and that's the environment they put you in, and you travel maybe one hundred miles and they can't hear if you cry or die in there. They told me you can make a report at any time and we'll make ours. (Kia from Uganda)

For others like Kia, bare life is embedded in night time removals - a psychologically violent institutional practice which makes women fearful for their lives:

In my mind I was always in the dark because they [the guards] come at night to take detainees and a big scream would wake you up. It's like she's not from my country, or in my family, but every time people go missing you think is this human being safe? And you get upset, then scared. (Kia from Uganda)

For Benyu, fleeing political violence only to be met with it in sanctuary personifies her as Agamben's homo sacer (a physical body without citizen rights and protections):

I remember being cuffed, bruised and bloodied from the last time they tried to deport me so you're already in a vulnerable place in your head...You know this is what I run away from - being thrown in jail by Zanu-PF men ${ }^{12}$ and now I'm actually in a cell like a terrorist when I'm really seeking protection. Y'know that really hit me hard! (Benyu from Zimbabwe)

As these quotes evidence, IRC practices replicate dehumanising, violent and punitive affects characteristic of other state-controlled institutions such as asylums and prisons (Moore, 2015). Yet IRC accounts go beyond a reported 
deterioration of Black, minority, ethnic mental health in prison (PRT, 2017), to raise the immorality of offering sanctuary 'in a setting that is the root cause' of psychological harm (Fazel and Silove, 2006: 251; Durcan et al, 2017). The IRC not only exacerbates existing mental disorders but actively causes disintegration of mental health (Phelps et al, 2014; Shaw, 2016) via practices of detaining people without criminal charge and night-time deportations. Whilst Shaw's initial inquiry into vulnerabilities has brought some improvement inside detention (most notably, a time-limit of seventy-two hours for pregnant women - Shaw, 2018: 14), its remit sidestepped the big issues of alternatives to detention and ending deportations ahead of case resolution (Shaw, 2016:8).

With no upper statutory time limit to how long someone can be confined in the IRC (Bosworth and Vannier, 2016), most considered detention as ethically indefensible or worse than prison:

There was one lady mixed in with us who was classed a foreign national, who killed her husband and her child and who had a history of fighting the guards. She said the toughest place they brought her was the IRC [laughs]. How can this be right when it's not a prison and we are not criminal? (Kia from Uganda)

Imprisonment, that's the worst thing when you're fleeing persecution. In fact it's worse than prison. In prison you count the days down to release and in detention you count them up because you don't know when you're coming out. (Linda from Zimbabwe)

Although the detention of non-citizens for immigration resolution or removal is an 'administrative' (as opposed to a 'criminal') process (Silverman and Griffiths, 2018: 2), comparison with prison assists detainees to make sense of the institution and its abjectifying practices (Bosworth, 2012). The fact it provides facilities like a gym, hair salon, or computer room does not distract from the 
reality of being imprisoned against their wishes. As Trinity from Nigeria remarks, this only constructs a 'glorified' prison environment. Here, women's accounts relay confinement as punishment, reflecting Sykes (1958) prison pains over autonomy, privacy, and relationship. As Wema from Malawi put it - 'you have doors locking and unlocking, no privacy to wash, no quiet to sleep, and nothing to do all day but stress'. In terms of the dissonance between state intent for removal centres and lived confinement as punishment, Sexton's (2015) model of penal consciousness urges policy responses based on how confinement is felt by inhabitants over institutional intent.

\section{Transgressive acts (from inhuman to gendered-cultural-political subjectivities)}

Since sovereign decisions are 'sustained in the minutiae of everyday [IRC] life' (Hall, 2010: 883), this is precisely where detainees find ambiguous space to critique and disrupt an ordered governance of bare life. Women's transgressive food-acts constitute micro acts of resistance against the dehumanising effects of the IRC on women's gendered, cultural and political subjectivities. This is one of several recipes shared by women:

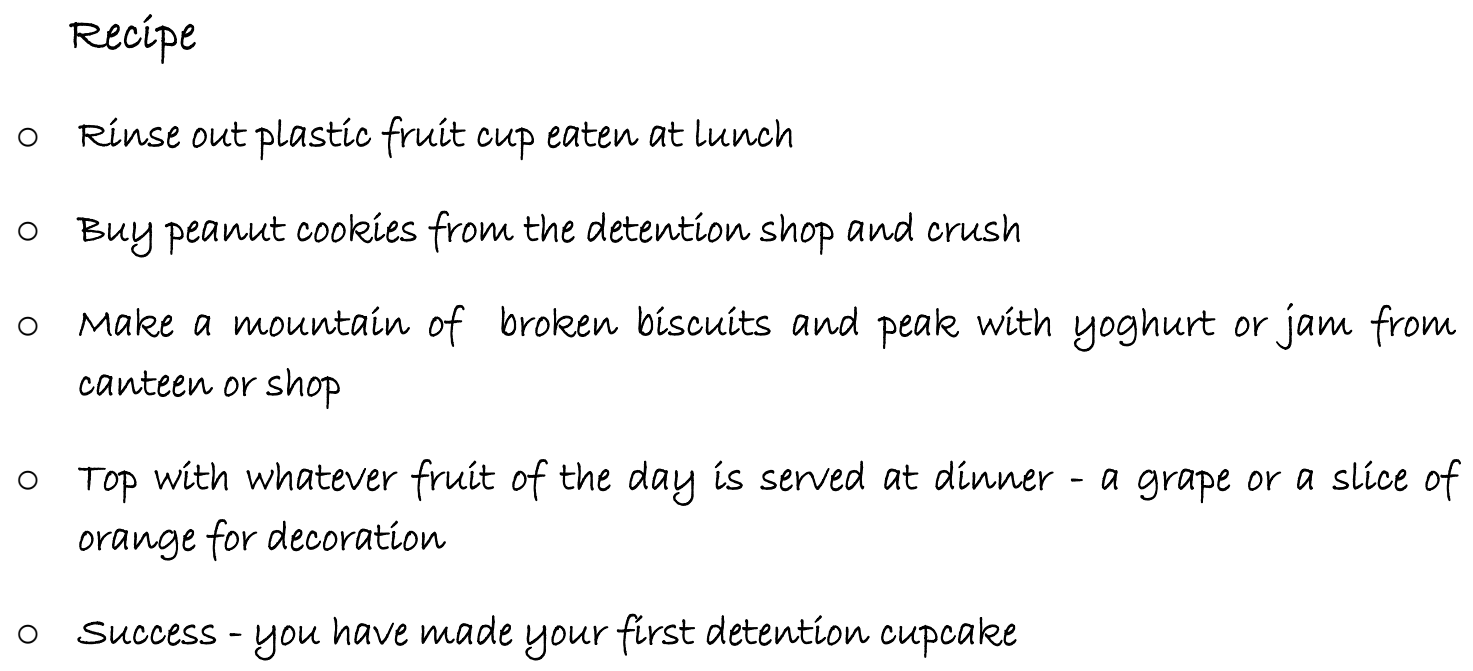


edjoe migrant-artist: detention cupcake sketch

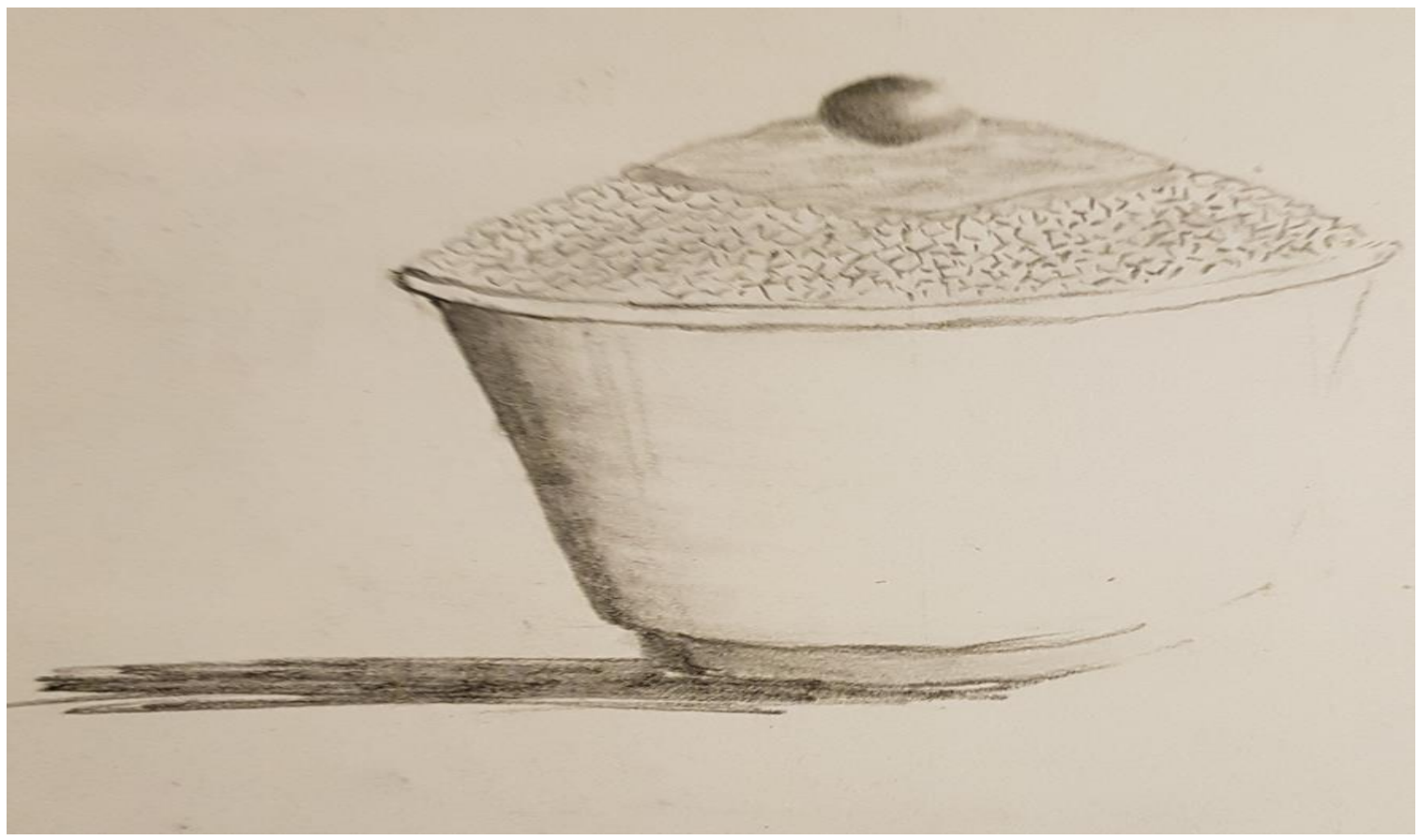

Food as prison punishment (Smoyer and Lopes, 2017), as a marker of asylum control (Squire, 2009), and an assault on identity (De Graaf and Kilty, 2016) are well documented within empirical and policy research on life under state control. Less so are the significance of food and embodied practices of cooking for female agency and identity maintenance inside the IRC. As exampled in the above recipe, women's dismantling of supplied food (saved from the canteen and bought from the IRC shop) and their rebuilding of ingredients into the detention cupcake is one way of reaffirming a gendered identity (Smoyer, 2016), since dessert-making is viewed as a female-intensive skill (De Vault, 1991).

Rebuilding cuisine is also a way of critically challenging the removal of cultural identity. As Benyu from Zimbabwe remarks to staff on seeing the set 
menu - 'You do know we're different nationalities'? Wema clarifies this in her account of supplied food as culturally-bare and unpalatable:

It really wasn't nice or healthy - plenty pastry and chips. In Africa we use a lot of flour but it comes from Maize meal. They were selling it in the shop so my friend, she made nice soup for us using tomato slices from the canteen, tomato puree and some spices from the shop, and we cooked it all together in the microwave - crumbling, sometimes dipping the maize strips into the soup like we did back home. (Wema from Malawi)

Given that prison food studies examine food-making in the context of single cultures, they are necessarily limited in their transference to the IRC both as places of 'hyper diversity' (Bosworth, 2013: 159) and places of liminality, where people await an asylum decision (Turnbull, 2015). When lives are ruled by external immigration forces, some choices over what to eat, when to eat it, and who with, afford women a rare moment of asylum agency. Women describe making food for one another following an official interview, or bad news from home, as restoring purpose and meaning to an otherwise bare life. Beyond this, Wema's attempt at recreating a homely dish nourishes her subjectivity as a migrant home-maker (Mankekar, 2005) as distinct to her administrative embodiment as deportable. (See De Angelis, for discussion of food and agency in the context of trafficked women).

Not eating meals most plainly interrupts the smooth running of the IRC since detainees are required to sign at sittings and gaps in registers reflect poorly on the institution and its level of care:

We started skipping meals, to begin with, just breakfast egg and toast. Then it became breakfast and lunch and slowly all meals that day. Before we know it, there was a knock on the door - we need to talk about this. We need to get your tick. (Fungi from Zimbabwe and Joli from Namibia) 
Three women took part in hunger strikes whilst inside the IRC. When asked why she was on hunger strike, Kia replied:

It's my right to protest - to go on hunger strike and be heard. It will do something political. The MP from my city came to see me and wanted to know about the hunger protest, my medical issues, and my reasons. I told him it will do something to protect the people [seeking asylum] who follow behind me. (Laughs) It wasn't as if the food was any good anyway. (Kia from Uganda, 33 days on hunger strike)

As evidenced in the extant literature, the hunger strike can be read as protest both in its embrace and refusal of politically bare life - see Edkins and Pin-Fat (2005) and Conlon (2016) for a discussion of these. However in these accounts, what becomes clear is that the duty of care imposed on the state by the Detention Services Order (HO, 03/2013), makes food refusal inside the IRC a political (as opposed to a private) matter. Once the refugee sector, the media, and politicians take up a hunger story, political invisibility is temporally interrupted. Of course, the hunger strike is simultaneously a costly challenge to women's own physical and mental wellbeing (Shaw, 2016).

\section{Transgressive acts (from outcast to belonging and ethical care)}

In addition to everyday practices involving food, micro-transgressions around faith are a way of contesting the loss of relationship inherent in bare life. Wema explains how forming a prayer group is a transgressive challenge to institutional restrictions placed on women's free association:

Every twelve midnight we'd go into our friend's room because she was a pastor. As we were praying, staff would knock to say you are making noise. We would say we are not making noise - you are. We can hear your footsteps in the corridor and your bunch of keys rattling. We are praying. But [laughs heartily] we are Pentecostal and when we sing it's very noisy... 
They weren't happy but they allowed it. They just said we were stubborn people. (Wema from Malawi)

As Bosworth and Kellezi (2016) reflect, engagement with religion is apposite in immigration since asylum is bound to people's pre- migration backgrounds and migratory histories. All the women in this study disclosed being people of Christian faith (there were not formally asked about religion in either the background or interview questions), and the interviewer was struck by the positivity of community in their faith narratives (Bauman, 2001). In sharing their spiritual beliefs, these women explain how faith brings relationship in three ways that critically challenge the sovereign exclusion from social connectivity and belonging.

The first challenge emanates from the physical in/exclusionary nature of chapel space. The chapel, as well as recreations of chapel as in Wema's account, are spaces of reduced surveillance and pastoral care inside a controlled and controlling institution. In keeping with Rowe's (2016) findings for the prison chapel, women request visits outside of service times and disclose using chapel space to assemble and talk. Whereas this interstitial space in prison also facilitates a trade in contraband (cigarettes and drugs), in the IRC the exchange is one of liaison and information, enabling women to organise themselves:

In chapel we had ladies from other wings, and when we had made friends - that's where we planned the hunger strike... When it was all over, they [the guards] said I wasn't going to be attending chapel any more. (Benyu from Zimbabwe, 31 days on hunger strike)

The second and third ways of reclaiming belonging link to the symbolic and social paradigms which church (and also synagogue, temple, and mosque) memberships bring for socially excluded individuals. While symbolic paradigms 
include a shared set of beliefs that affect the way in which members understand reality (for example, a relationship with a deity promises welcome and citizenship in a future ethereal world (O'Neill, 2009)), the temporal social value is one of belonging in networks tasked with ethical care and practical human charity (Ebaugh and Chafetz, 2000; Tronto, 2005). As Kia explains, faith connects people both prayerfully and practically to communities outside detention:

My local church was like a small community praying and campaigning for people like me. When I had a problem inside they rang round to get legal advice, and when I was to be released they arranged for me stay in the vicarage. (Kia from Uganda)

Inside the walls of the IRC, women situate faith-related kindness in antithesis to detention-related bareness of belonging and care:

I shared a room with different ladies but the first I remember was a Muslim... She came from Kenya but had been living in Britain a long time. She was very good to new detainees like me - showing us where to eat, advising us on solicitors, helping us use the computer room. (Joli from Namibia)

The first lady I shared with, I think she was Russian Orthodox, and the way they arrested me, I didn't have anything with me and she gave me her wrap. I still have it. I don't want to throw it away. She was asking for a flight. But they play evil tricks with you. When people want to go back they don't send them back. (Kia from Uganda)

I felt sorry for the incontinent Pentecostal lady who was in a wheel chair. It was us - not the guards - who cleaned her and her room. I used to pray with her. When the news came - from the bottom of my heart - if I could 
have given my release to her, I would have given her my freedom. (Wema from Malawi)

As Adogame (2013: 107) cautions, social capital as a 'collective good' runs a risk of reinforcing class and ethnic divisions across socially heterogeneous groups - a pattern found in Bosworth and Kellezi's (2014) IRC research. In this study, however, compassionate actions borne of faith (with all faiths requiring love, care and respect of other) and transcending human and doctrinal differences between them, pose a critical challenge to unethical and uncaring IRC governance. Of course, a truer measure of belonging is 'active mixing' beyond institutionally imposed time and space (Ager and Strang (2004: 8). This is so strongly embodied by Linda from Zimbabwe that her post-release actions can be read as reversing the in/exclusionary table on the sovereign host. As Linda explains, each year asylum seekers from her church 'cook a proper Christmas dinner for British citizens' and support them with 'their social problems' (alcohol, drugs, loneliness), 'so they get a happy day'.

\section{Discussion}

These findings on biopower and political agency raise a number of important issues. Carceral punishment and migrant resistance will be analysed in greater detail.

\section{Carceral punishment}

Paying attention to women's narratives of IRC confinement builds understanding of immigration detention as punishing the body, mind, and soul of people seeking asylum (Foucault, 1977). Not intended as sites of punishment, its lived reality mirrors a 'criminal justice imagination' (Bosworth, 2014) described by those it confines as 'looking' and 'feeling' like prison. In this respect, there is confluence not only with a global camp system of refugee segregation and control (UNHCR, 2014), but also with a domestic prison estate and overarching 
criminal justice system. But there are significant differences between the immigration estate and the criminal justice prison estate, especially over how and whom these institutions confine. On the slim but positive side, IRC detainees have access to technologies (mobile phones without cameras and a computer room where they can receive and send emails to solicitors and case holders Home Office, 04/2016), a vital provision since on-site officers action but do not make case decisions. There is also momentum for an internet access policy facilitating contact with immigration websites and providing country-specific updates (Shaw, 2018: 15-16). On the weightier but negative side, women's accounts raise legal deficits, in particular, no automatic judicial review of decisions to detain and no upper limit to how long a person can be detained (Bosworth, 2013). Although a new regime for immigration bail came into force in January, 2018, - initiating automatic bail hearings for anyone detained for four months (Home Office, 2018: 57) - the prospect of indefinite detention for those refused bail remains intact. This effectively means there can be no sentence planning, for example, for mental health support and a diversity of needs on release. After all, detainees are waiting to be expelled and the state has no duty to prepare them for return (Bosworth, 2013).

Crucially, where there is difluence between systems, the fault-line rests on the political distinction immigration draws between citizen and non-citizen and Agamben's (1998) work is helpful for conceptualising this distinction. Understood as subjecting people seeking asylum to the authority of (inclusion within) state law and simultaneously denying (excluding them) from legal rights afforded to national prisoners, this distinction justifies powers divorced from the due processes of criminal law. Clear examples of this (drawn from background interviews) are powers of administrative arrest without a warrant of people with missing or incorrect papers (Home Office, 2016: 15), and the detention without criminal charge of asylum seekers pursuant to removal. Looking to experiential accounts, women query the legitimacy of immigration incarceration within 
asylum; recognising 'it's not a prison and we are not criminal' and voicing it as 'worse than prison'. In so far as legal definition of immigration detention and deportation remains administrative, its experience as carceral punishment is likely to evade legal review and policy overhaul (Bowling, 2013).

Beyond legitimacy, this lived distinction between citizen and non-citizen is a point of intersectionality for asylum and race and who gets confined (see Bosworth, Parmar and Vazquez, 2018). Whilst in the prison context, there is frequent over-representation of the 'underclass' (Feeley and Simon, 1992) or society's poor (Reiman and Leighton, 2010), within immigration detention those confined are any and potentially all racialised migrant bodies, as illustrated by the Windrush generation. Despite migrating from the Commonwealth between 1948 and 1972 and lawfully living in the UK for decades, many were detained in Immigration Removal Centres and some deported during 2017-18, for their inability to prove an indefinite leave to remain status (see National Audit Office, 2018). Within the present study, racialised migrant bodies fit into one of the following three administrative categories: that of asylum seeker (like Wema); Hales and Gelsthorpe's (2012) economic migrants who become trafficked (like Anita); and Berry's (2009: 11) 'virtual nationals' - non-nationals under consideration for removal but who have lived in the host country for a significant period (like Linda and many Windrush citizens). Irrespective of classification, all face the same real threat of forced removal.

\section{Migrant resistance}

Against the backdrop of biopolitical findings for an immigration estate with harmful institutional practices, the 'idea' of asylum seekers 'being / becoming political under detention' is, as Puggioni (2014: 565) suggests, 'anomalous if not an oxymoron'. Yet, as Puggioni argues for non-nationals in an Italian camp context, because protest about unequal rights, discriminatory treatment, arbitrary violence and belonging relate to the political sphere, both these actions 
and their actors assume political properties despite an absence of legal status. Within critical migration studies, there is a growing body of resistance literature which acknowledges a political dimension to camp space and camp-like institutions. This body of literature recognises the agency of forced migrants (Puggioni, 2006; Redclift, 2013); capacity for resisting biopolitical controls (Isin and Rygiel, 2007; Ellermann, 2010; Conlon, 2016); and the contestability of power relations within camp/camp-like spaces like the Calais 'Jungle', France (Rygiel, 2011); the Mosney Accommodation Centre, Ireland (Conlon, 2016); and 'Refugee Occupy', Hong Kong (Vecchio and Ham, 2018). Going beyond Agamben's monolithic view of the camp, this body of literature sees camp space as more than a 'void of law and political life'. As Ramadan (2013:70) observes, it sees 'who and what is in the camp [and] how they interrelate and interact'. In other words, power relations are constitutive of everyday practices and relations inside these institutions which, in turn, open them out to negotiation and transgressive challenge from inhabitants (Redclift, 2013).

Fitting with such textual readings on biopolitical space, Foucault's (1997) critical attitude captures displays of political agency as performed within the in/exclusive spaces and routines of institutional control. In looking to experiential findings, women's transgression of an IRC restriction on free association can thus be read as an example of everyday micro-politics - one contesting institutionally imposed isolation. Similarly, everyday practices surrounding food not only attest to women's human agency, but near recreations of homely recipes restore a degree of gendered and cultural subjectivity - defying institutional reification as deportable bodies. Women's everyday engagement in faith-related activity subverts their non-belonging in wider society - since faith connects them to external religious networks, each tasked with prayerful and charitable obligations towards their members. Combined, women's food and faith-related transgressions pose a political micro-challenge to the certitude of their asylum lives as wholly regulated by those in authority. Whilst mindful of 
Ramadan's (2013: 74) plea not to replace 'the Agambenian vision of refugees cast out of the political realm with a vision of the camp where everything is political', researching life inside reveals the nuances of in/exclusion, as played out inside the inaccessible and under-researched space of the IRC.

\section{Conclusion}

On a final note, in so far as a critical challenge raises issues of violence, control, culture, race and gender in the detention of persons seeking asylum, its micro and often temporary nature reminds us of the power and precarity of sovereign decision making - at its most plain when placing these people in detention in the first place. Whilst the overall number of people passing through the IRC fell between 2016 and 2017 (after a number of predominantly male institutions closed: Silverman and Griffiths, 2018), this reduction in bed space has not profited women (Shaw, 2018), and the reality of immigration detention for anyone seeking asylum in the UK is far from being or becoming a rarity (Ohtani and Phelps, 2016). In light of uncertainty over governmental targets on voluntary and enforced removals (Bolt, 2015; Home Affairs Committee, 2018), and the deeply politicised nature of immigration discourse, the need for independent academic inquiry grows ever urgent. As Bosworth and Kellezi (2016) assert, without the critical commentary there can be no public, moral or policy momentum for asylum reform.

Researching women's everyday treatment as part of this study tells us a great deal about the harmful nature of biopolitical practices inside this researcher-inaccessible institution, and moves us to ask why the UK Government remains outside the European Returns Directive on a statutory upper time limit on detention (CoEP, 2008). Beyond the profoundly troubling aspects mined through Agamben's work on bare life and in/exclusion, researching women's everyday activities builds understanding of the IRC as more than biopolitical space, and of inhabitants as more than merely bare life. 
To research narratives of everyday treatment and activity on food, faith, and social relations is to comprehend micro-transgressions as everyday acts of politics inside detention: acts through which women in this study re-appropriate subjectivities, display resistance to biopolitical control, and disrupt a smooth and orderly administration of their asylum deportability. Against an established trend in allowing community groups inside the IRC to befriend (see AVID, the association of visitors to immigration detainees) and run workshops (see the charity 'Music in Detention'), the doors of the IRC remain foreseeably closed to researchers. Until the Home Office and custodial companies allow researchers in, it is remarkable women like these who make their own plight known and raise the critical challenge to a continued asylum governance 'like that, by these people, at this price', for others who follow them.

\section{Acknowledgements}

Heartfelt thanks go to the three anonymous reviewers and the editorial team at Social Policy and Society for their inspired comments towards this final version of the manuscript.

\section{Notes}

1. Whilst the article refers to people seeking asylum as asylum seekers, this label is problematic because it denotes a temporal legal status.

2. To follow critiques of Agamben vis-à-vis resistance, see Zembylas, 2010.

3. Before closure of IRC Haslar and IRC Dover in 2015, and the Verne in 2018, there were 11 IRCs.

4. Although Cedars closed at the end of 2016, a replacement PDA facility opened at IRC Tinsley House in May 2017.

5. As part of a family group, children can also be held for 3 days in pre-departure accommodation and up to 7 days with ministerial approval.

6. See: https://www.youtube.com/watch?v=VF9AuqPaRtY [accessed 10.01.2019].

7. See: https://www.channel4.com/news/yarls-wood-immigration-removal-detention-centre-investigation [accessed 10.01.2019].

8. In spite of Panorama's exposé, the G4S contract was extended to 2020.

9. Hospitality is a politically contested frame of reference. To follow this discussion - see: Darling (2009); Squire and Darling (2013).

10. She was subsequently persuaded to take the cash to spend on her young daughter.

11. Interviews lasted between 2 and 3 hours, with women welcoming academic interest in the IRC.

12. The Zanu-PF party endorsed the recently deposed Robert Mugabe for president of Zimbabwe 


\section{References}

Adogame, A. (2013), The African Christian Diaspora: New Currents and Emerging

Trends in World Christianity, London: Bloomsbury.

Agamben, G. (1997), 'The camp as the nomos of the modern', in H. De Vries and S.

Weber (eds.), Violence, Identity and Self-Determination, Redwood City, CA:

Stanford University Press, 106-118.

Agamben, G. (1998), Homo Sacer: Sovereign Power and Bare Life, trans. D.

Heller-Roazen, Stanford CA: Stanford University Press.

Agamben, G.(2000), Means Without End: Notes on Politics, trans. V.Vinetti and C.

Casarino, Minneapolis: University of Minnesota Press.

Agamben, G. (2005), State of Exception, Chicago IL: University of Chicago Press.

Ager, A. and Strang, A. (2004), 'The experience of integration: a qualitative study of refugee integration in the local communities of Pollockshaws and Islington', https://www.lemosandcrane.co.uk/dev/resources/Home\%200ffice\%20\%20The\%20Experience\%20of\%20Integration.pdf [accessed 05.09.2017].

Aliverti, A. (2016), 'Doing away with decency? Foreigners, punishment and the liberal state', in A. Eriksson (ed.), Punishing the Other: The Social Production of Immorality Revisited, London: Routledge, 124-144.

Amoore, L. and Hall, A. (2013), 'The clown at the gates of the camp: sovereignty, resistance and the figure of the fool', Security Dialogue, 44, 2, 93-110.

Barnett, C. and Bhogal, I. (2009), Becoming a City of Sanctuary: A Practical Handbook with Inspiring Examples, Ripon: Plug and Tap Publishers.

Bauman, Z. (1993), Postmodern Ethics, Oxford: Blackwell.

Bauman, Z. (2001), Community: Seeking Safety in an Insecure World, Cambridge: Polity Press.

Bauman, Z. (2004), Modernity and its Outcasts, Cambridge: Polity Press.

Berry, E. (2009), 'The deportation of 'virtual national' offenders: the impact of the ECHR and EU law', Journal of Immigration Asylum and Nationality Law, 23, 1, 11-23.

Bloch, A. and Schuster, L (2005), 'At the extremes of exclusion: deportation, 
detention and dispersal', Ethnic and Racial Studies, 28, 3, 491-512.

Bolt, D. (2015), An Inspection of Removals October 2014-March 2015, London: HMSO.

Bosworth, M. (2012), 'Subjectivity and identity in detention: punishment and society in a global age', Theoretical Criminology, 16, 2, 123-140.

Bosworth, M. (2013), 'Can immigration detention be legitimate? Understanding confinement in a global world', in K.F. Aas and M. Bosworth (eds.), The Borders of Punishment: Migration, Citizenship, and Social Exclusion, Oxford: Oxford University Press, 149-165.

Bosworth, M. (2014), 'Inside immigration detention centres: uncoupling detention from a criminal justice imagination', http://blogs.Ise.ac.uk/politicsandpolicy/inside-immigration-detention-centres/ [accessed 22.08.2017].

Bosworth, M. (2017), 'Border criminology and the changing nature of penal power', in A. Liebling, S. Maruna and L. Mc Ara (eds.), The Oxford Handbook of Criminology, Oxford: Oxford University Press, 373-390.

Bosworth, M. and Kellezi, B. (2014), 'Citizenship and belonging in a women's immigration detention centre', in C. Phillips and C. Webster (eds.), New Directions in Race and Ethnicity, Abingdon: Routledge, 80-96.

Bosworth, M. and Kellezi, B. (2016), 'Doing research in immigration removal centres: ethics, emotions and impact', Criminology and Criminal Justice, 17, 2, 121137.

Bosworth, M. and Vannier, M. (2016), 'Human Rights and immigration detention in France and the UK', European Journal of Migration and Law, 18, 2, 157-176.

Bosworth, M., Hoyle, C. and Dempsey, M.M. (2011), 'Researching trafficked women', Qualitative Inquiry, 17, 9, 769-779.

Bosworth, M., Parmar, A. and Vazquez, Y. (eds.), (2018) Race, Criminal Justice and Immigration Control: Enforcing the Boundaries of Belonging, Oxford: OUP. Bowling, B. (2013), 'Epilogue: the borders of punishment: towards a criminology of 
mobility', in K.F. Aas and M. Bosworth (eds.), The Borders of Punishment: Migration, Citizenship, and Social Exclusion, Oxford: Oxford University Press, 291-306.

Braun, V. and Clarke, V. (2006), 'Using thematic analysis in psychology', Qualitative Research in Psychology, 3, 2, 77-101.

Canning, V. (2014), 'Violence in Britain: behind the wire at immigration removal centres', https://theconversation.com/violence-in-britain-behind-the-wire-atimmigration-removal-centres-25519 [accessed 13.06.2017].

Canning, V. (2017), 'Brutality of British immigration detention system laid bare', https://theconversation.com/brutality-of-british-immigration-detention-systemlaid-bare-83396 [accessed 12.12.2017].

Carnet, P., Blanchard, C. and Ellis, J. (2014), The Azure Payment Card: The Humanitarian Cost of a Cashless System, London: British Red Cross.

Conlon, D. (2016), 'Hungering for freedom: asylum seekers' hunger strikes rethinking resistance as counter-conduct', in D. Moran, N. Gill and D. Conlon (eds.), Carceral Spaces: Mobility and Agency in Imprisonment and Migrant Detention, London: Routledge, 133-148.

Council of the European Parliament. (CoEP). (16/12/2008), 'Directive 2008/115/EC on common standards and procedures in member states for returning illegally staying third country nationals', $\underline{\text { https://eur- }}$ lex.europa.eu/LexUriServ/LexUriServ.do?uri=OJ:L:2008:348:0098:0107:EN:PD F [accessed 04.01.2019].

Critchley, S. (2000), 'Remarks on Derrida and Habermas', Constellations, 7, 455465.

Darling, J. (2009), 'Becoming bare life: asylum, hospitality and the politics of encampment', Environment and Society D: Society and Space, 27, 649-665.

De Angelis, M. (2016), Human Trafficking: Women's Stories of Agency, Newcastle: CS Press.

De Genova, N. (2010), 'The deportation regime: sovereignty, space and the freedom 
of movement', in N. De Genova and N. Peultz (eds.), The Deportation Machine: Sovereignty, Space, and the Freedom of Movement, Durham NC: Duke University Press, 33-67.

De Graaf, K. and Kilty, J.M. (2016), 'You are what you eat: exploring the relationship between women, food and incarceration', Punishment and Society, 18, 27-46.

De Vault, M.L. (1991), Feeding the Family: The Social Organisation of Caring as Gendered Work, Chicago, IL: University of Chicago Press.

Doherty, B. and Davidson, H. (2017), 'Australia's off-shore detention regime is a brutal and obscene piece of self-delusion', The Guardian, 29 November.

Durcan, G., Stubbs, J. and Boardman, J. (2017), Immigration Removal Centres in England: A Mental Health Needs Analysis, London: Centre for Mental Health, Ebaugh, H. and Chafetz, J. (2000), Religion and the New Immigrants, Oxford: AltaMira.

Edkins, J. and Pin-Fat, V. (2004), 'Introduction: life, power, resistance', in J. Edkins,

V. Pin-Fat and M.J. Shapiro (eds.), Sovereign Lives, London: Routledge,1-123. Edkins, J. and Pin-Fat, V. (2005), 'Through the wire: relations of power and relations of violence', Millenium: Journal of International Studies, 34, 1, 1-24.

Ellermann, A. (2010), 'Undocumented migrants and resistance in the liberal state', Politics and Society, 38, 3, 408-429.

Fassin, D. (2011), 'Policing borders, producing boundaries: the governmentality of immigration in dark times', Annual Review of Anthropology, 40, 213-226.

Fazel, M. and Silove, D. (2006), 'Detention of refugees', British Medical Journal, 332, 251-252.

Feeley, M. and Simon, J. (1992), 'New penology: notes on the emerging strategy of corrections and its implications', Criminology, 30, 4, 449-474.

Fekete, L. (2008), 'Asylum rights: grinding down the Human Rights defenders', European Race Bulletin, no. 65, Autumn 2008.

Foucault, M. (1977), Discipline and Punish: The Birth of the Prison, London: Allen Lane.

Foucault, M. (1997), 'What is critique?', in S. Lotringer (ed.), The Politics of Truth, 
Los Angeles: Semiotext(e), 41-81.

Global Detention Project (GDP). (2016), 'United Kingdom immigration detention

profile: UK domestic law', https://www.globaldetentionproject.org/wpcontent/uploads/2016/10/UK-Immigration-Detention-Report.pdf [accessed 11.07.2017].

Hall, A. (2010), 'These people could be anyone: fear, contempt (and empathy) in a British immigration removal centre', Journal of Ethnic and Migration Studies, 36, 6, 881-898.

Hall, A. (2012), Border Watch: Cultures of Immigration Detention and Control, London: Pluto.

Hales, L. and Gelsthorpe, L. (2012), The Criminalisation of Migrant Women, Cambridge: Institute of Criminology, University of Cambridge.

Hollway, W. and Jefferson, T. (2000), Doing Qualitative Research Differently, London: Sage.

Home Affairs Committee Deb. (08.05.2018). 'HC 913 Immigration debate', http://data.parliament.uk/writtenevidence/committeeevidence.svc/evidencedocu ment/home-affairs-committee/immigration-detention/oral/82531.pdf [accessed 04.01.2019].

Home Office. (HO). (03/2013), 'Detention services order', http://www.insidetime.org/download/rules \& policies/IRC\%20(Immigration\%20 Removal\%20Centres)/DSO-2013-03 fluid-food-refusers.pdf [accessed 04.09.2017].

Home Office. (HO). (04/2016), 'Detention services order',

https://assets.publishing.service.gov.uk/government/uploads/system/uploads/att achment data/file/523833/DSO 04-2016 Detainee access to Internet.pdf [accessed 20.12.2018].

Home Office. (HO). (2016), 'Coercive powers: overview', https://assets.publishing.service.gov.uk/government/uploads/system/uploads/attach ment data/file/511251/Coercive powers v1.0.pdf [accessed 20.12.2018]. 
Home Office. (HO). (2017a), Immigration Statistics January-March 2017, London: Home Office.

Home Office. (HO). (2017b), Immigration Statistics October-December 2016,

London: Home Office.

Home Office. (HO). (2018), 'Immigration bail',

https://assets.publishing.service.gov.uk/government/uploads/system/uploads/att achment data/file/733313/immigration-bail-v3.pdf [accessed 20.12.2018].

Isin, E. and Rygiel, K. (2007), 'Abject spaces: frontiers, zones, camps', in E.

Dauphinee and C. Masters (eds.), The Logics of Biopower and the War on Terror, New York: Palgrave Macmillan, 181-205.

Levy, C. (2010), 'Refugees, Europe, camps / state of exception: 'into the zone', the

European Union and extraterritorial processing of migrants, refugees and asylum-seekers (theories and practice)', Refugee Survey Quarterly, 29, 1, 92119.

Malkki, L. (1995), 'Refugees and exile: from 'refugee studies' to the national order of things', Annual Review of Anthropology, 24, 493-523.

Mankekar, P. (2005), '"India Shopping": Indian grocery stores and transnational configurations of belonging', in J.L. Watson and M.L. Caldwell (eds.), The Cultural Politics of Food and Eating: a Reader, Oxford: Blackwell, 197-214.

Moore, J.M. (2015), 'Prison - more than detention?', Criminal Justice Matters, 102, 1, 11-12.

McNevin, A. (2011), Contesting Citizenship: Irregular Migrants and New Frontiers of the Political, New York: Columbia University Press.

McGregor, J. (2011), 'Contestations and consequences of deportability: hunger strikes and the political agency of non-citizens', Citizenship Studies, 15, 5, 597611.

McHugh, J. (2015), 'Roszke refugee camp update: makeshift shelter housing thousands in Hungary fleeing sectarian violence is accused of Human Rights violations', International Business Times, 9 April.

National Audit Office. (NAO). (2018), 'Handling of the Windrush situation', 
https://www.nao.org.uk/wp-content/uploads/2018/12/Handling-of-the-Windrushsituation-1.pdf [accessed 20.12.2018].

Nyers, P. (2004), 'What's left of citizenship?', Citizenship Studies, 8, 3, 203-215.

O'Donoghue, A. (2015), 'Sovereign exception: notes on the thought of Georgio

Agamben', Critical Legal Thinking,

http://criticallegalthinking.com/2015/07/02/sovereign-exception-notes-on-the-

thought-of-giorgio-agamben/ [accessed 03.01.2019].

Ohtani, E. and Phelps, J. (2016), Without Detention: Opportunities for Alternatives, London: Detention Action.

O'Neill, K. (2009), 'But our citizenship is in heaven: a proposal for the future study of

Christian citizenship in the global south', Citizenship Studies, 13, 4, 333-348.

Phelps, J., Ben Du Preez, A., Kuka, H., Carette, M., Sharif, M. and Souleymane.

(2014), The State of Detention: Immigration Detention in the UK in 2014, London: Detention Action.

Prison Reform Trust. (PRT). (2017), Counted Out: Black, Asian and Minority Ethnic

Women in the Criminal Justice System, London: PRT.

Puggioni, R. (2006), 'Resisting sovereign power: camps in-between exception and dissent', in J. Huysmans, A. Dobson and R. Prokhovnik (eds.), The Politics of

Protection: Sites of Insecurity and Political Agency, Oxford: Routledge,68-83.

Puggioni, R. (2014), 'Speaking through the body: detention and bodily resistance in

Italy', Citizenship Studies, 18, 5, 562-577.

Ramadan, A. (2013), 'Spatialising the refugee camp', Transactions of the Institute of British Geographers, 38, 65-77.

Redclift, V. (2013), 'Abjects or agents? Camps, contests, and the creation of political space', Citizenship Studies, 17, 3-4, 308-321.

Reiman, J. and Leighton, P. (2010), The Rich get Richer and the Poor get Prison: Ideology, Class, and Criminal Justice, Boston: Pearson.

Rowe, A. (2016), 'Tactics, agency and power in women's prisons', British Journal of Criminology, 56, 2, 332-349.

Rygiel, K. (2011), 'Bordering solidarities: migrant activism and the politics of 
movement and camps at Calais', Citizenship Studies, 15, 1, 1-19.

Sexton, L. (2015), 'Penal subjectivities: developing a theoretical framework for penal consciousness', Punishment and Society, 17, 1, 114-136.

Shaw, S. (2016), Review into the Welfare in Detention of Vulnerable People, London: HMSO

Shaw, S. (2018), Assessment of Government Progress in Implementing the Report on the Welfare in Detention of Vulnerable People, London: HMSO.

Silverman, S.J. (2017), Immigration Detention in the UK, Migration Observatory Briefing, UOMPAS: University of Oxford, http://migrationobservatory.ox.ac.uk/wp-content/uploads/2016/04/BriefingImmigration Detention-2.pdf [accessed 04.01.2017].

Silverman, S.J. and Griffiths, M.E.B. (2018), Immigration Detention in the UK, Migration Observatory Briefing, COMPAS: University of Oxford, https://migrationobservatory.ox.ac.uk/resources/briefings/immigration-detentionin-the-uk/ [accessed 11.10.2018].

Smoyer, A. (2016), 'Making fatty girl cakes: food and resistance in a women's prison', The Prison Journal, 96, 2, 191-209.

Smoyer, A. and Lopez, G. (2017), 'Hungry on the inside: prison food as concrete and symbolic punishment in a women's prison', Punishment and Society, 19, 2, 240 255.

Squire, V. (2009), The Exclusionary Politics of Asylum, Hampshire: Palgrave Macmillan.

Squire, V. and Darling, J. (2013), 'The minor politics of rightful presence: justice and relationality in City of Sanctuary', International Political Sociology, 7. 1, 59-74.

Sykes, G. (1958), The Society of Captives, Princeton NJ: Princeton University Press. Tronto, J. (2005), 'Care as the work of citizens: a modest proposal', in M. Friedman (ed.), Women and Citizenship, Oxford: Oxford University Press, 130-145.

Turnbull, S. (2015), 'Stuck in the middle: waiting and uncertainty in immigration detention', Time and Society, 25, 1, 61-79.

United Nations High Commissioner for Refugees. (UNHCR). (2014), World at War, 
Geneva: UN Refugee Agency, http://www.unhcr.org/556725e69.pdf [accessed 06.07.2018].

United Nations High Commissioner for Refugees. (UNHCR). (2016), Global Trends:

Forced Displacement in 2016, Geneva: UN Refugee Agency, http://www.unhcr.org/5943e8a34.pdf [accessed 12.07.2017].

Vecchio, F. and Ham, J. (2018), 'From subsistence to resistance: asylum-seekers and the other 'Occupy' in Hong Kong', Critical Social Policy, 38, 2, 201-221.

Zembylas, M. (2010), 'Agamben's theory of biopower and immigrants / refugees/ asylum seekers: discourses of citizenship and the implications for curriculum theorising, Journal of Curriculum Theorising, 26, 2, 31-45.

Ziarek, E.P. (2008), 'Bare life on strike: notes on the biopolitics of race and gender', South Atlantic Quarterly, 107, 1, 89-105. 